\title{
PENGARUH NILAI AKUNTANSI TERHADAP PENGELOLAAN KEUANGAN MAHASISWA (STEBIS IGM)
}

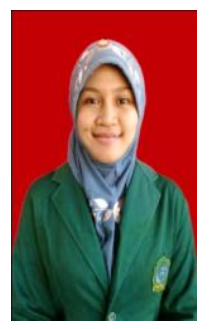

\author{
FADILLA \\ Dosen Sekolah Tinggi Ekonomi dan Bisnis Syariah Indo Global Mandiri \\ (STEBIS IGM) Palembang \\ Email : haninfadilla423@gmail.com
}

\begin{abstract}
ABSTRAK
Penelitian ini bertujuan untuk menetahui bagaimana pemahaman Mahasiswa STEBIS (Sekolah Tinggi Ekonomi dan Bisnis Syariah) dalam pelajaran Akuntansi, serta sejauh mana pemahaman mahasiswa tersebut dapat berpengaruh dalam pengalokasian keuangan mereka. Pemahaman mahasiswa diukur dengan nilai Akuntansi, sedangkan pengelolaan keuangan di ukur dengan menghitung berapa banyak pengeluaran mereka setiap bulannya yang di-proxi dengan uang saku/ uang jajan mereka setiap bulannya. Populasi dalam penelitian ini adalah mahasiswa STEBIS angkatan tahun 205-2016, dari program studi perbankan dan ekonomi syariah. Metode analisis yang digunakan adalah regeresil inier sederhana. Hasil uj t menunjukkan bahwa nilai akuntansi berpengaruh terhadap uang saku. Nilai signifikansinya adalah $-0,016$.
\end{abstract}

Kata Kunci : Nilai Akuntansi, Uang Saku

\section{DASAR PEMIKIRAN}

\subsection{Latar Belakang}

Pada hakikatnya manusia di dunia ini diberkati oleh Allah S.W.T. dengan berbagai macam kecerdasan baik kecerdasan spiritual, emosional maupun intelegensi. Kecerdasan emosional merupakan kecerdasan yang berhubungan dengan pengendalian diri dari amarah, keinginan yang mengebu-gebu dan lain sebagainya.

Adapun kecerdasan spiritual berhubungan dengan kedekatan seseorang dengan Tuhannya yang pada akhirnya akan berpengaruh terhadap hubungan seseorang dengan manusia yang lainnya. Seperti menolong sesama, memberikan rasa empati kepada sesama manusia dan lain sebagainya. Sedangkan kecerdasan intelegensi berhubungan dengan kemampuan seseorang dalam memahami sesuati yang berhubungan dengan pengetahuan.

Kecerdasan intelegemsi mempengaruhi daya tangkap seseorang dalam memahami lingkungan sekitarnya. Banyak penelitian yang menunjukkan bahwa semakin cerdas seseorang maka semakin mudah bagi dia untuk menjalankan pekerjaan/ tanggun jawab yang dibebankan kepadanya. Orang-orang cerdas dan berilmu biasa juga dapat memecahkan masalahnya dengan baik dan melihat segala objektif. Jika orang yang cerdas ini dapat mengaplikasikan ilmu yang diperoleh dalam kehidupan seharihari maka hal itu akan lebih baik lagi.

Hal ini dapat peneliti ilustrasikan misalkan ada seorang anak yang pandai dalam pelajaran Bahasa Indonesia, yang 
ditunjukkan dengan nilai-nilainya yang bagus dalam mata pelajaran tersebut. Anak tersebut juga mendapatkan beberapa macam penghargaan dalam berbagai lomba Bahasa Indonesia seperti lomba pidato Bahasa Indonesia, menulis karya ilmiah, dan mengarang. Dalam kesehariannya anak ini memilikitutur bahasa yang halus dan santun.

Anak tersebut memiliki sifat seperti ini karena anak inimengaplikasikan pengetahuan Bahasa Indonesia yang dia miliki dalam kehidupan sehari-hari. Dalam pelajaran Bahasa Indonesia dijelaskan bahwa nada bicara yang keras dapat menimbulkan kemarahan dan salah paham lawan bicara kita. Sebaliknya berita buruk tapi disampaikan dengan bahasa yang lemah lembut dengan nada yang terarah akan membuat si penerima berita (lawan bicara kita bisa menerima kabar tersebut dengan hati yang cukup lapang dan tenang. Karena orang yang menyampaikan berita tersebut dan orang-orang yang ada disekitarnya memberikan aura yang positif bagi dirinya

Anak tersebut juga mendapatkan informasi bahwa serbu satu masalah di dunia ini adalah komunikasi. Oleh sebab itu anak ini menjaga tata bicaranya, bahasanya, agar tidak menyakiti perasaan orang lain. Jika perkataannya akan membuat orang lain sakit hat/murka maka dia lebih baik diam. Jika semua oranh cerdas seperti ini maka kehidupan masyarakat akan menjadi lebih baik. Orang-orang cerdas betul-betul mengaplikasikan keilmuan yang dia miliki. Apalagi jika para sarjana dan ahli pada bidang tertentu dapat mengaplikasikan keilmuaanya dalam kehidupan sehari-hari.

Salah satu kecerdasan yang harus dimiliki oleh manusia salah satunya sebagai mahasiswa adalah kecerdasan finansial, yaitu kecerdasan dalam mengelola keuangan pribadi. Mahasiswa telah dibekali ilmu keuangan dengan tujuan memajukan sumber daya manusia yang berdaya saing di dunia kerja dan mampu menerapkan teori yang didapatkan untuk kehidupan sehari-hari. Dengan bekal tersebut mahasiswa diharapkan memiliki kemampuan memanajemen keuangan pribadinya dengan baik. (Wulandari dan Luqman, $2015: 1$ )

Pemahaman kecintaan akan uang di kalangan para mahasiswa juga dianggap penting mengingat mereka adalah calon anggota profesi atau profesional di bidang mereka masing-masing serta calon pemimpin dan manajer di masa mendatang yang harus mampu memanajemen keuangan dengan baik. Menurut Danes (dalam Nidar, 2012 belajar bagaimana mengelola uang (money management) adalah salah satu hal yang penting yangharus dimiliki seseorang. Dalam penelitian mengenaikeuangan di lapangan sering membahas masalah yang berhubungan dengan keuangan individu dimana dikenal sebagai keuangan pribadi (personal finance).(Wulandari dan Luqman, $2015: 2$ ).

Menurut Husnan dan Pudjiastuti (2006:1)“Keuangan pribadi merupakan aplikasi dari konsep konsep keuangan untuk pengambilan keputusan keuangan pada tingkat individu". Di Indonesia banyak ditemuipenelitian mengenai keuangan publik, tetapi masih sedikit yang membahas mengenai keuangan pribadi. Melek keuangan pribadi merupakan elemen penting dalam membuat keputusan keuangan dan peningkatan kesejahteraan. Melek keuangan pribadi dapat diartikan sebagai kemampuan untuk mengetahui dan memahami pengelolaan keuangan pribadi. (Wulandari dan Luqman, 2015 : 2). 
Adapun beberapa penelitian yang meneliti tentang pengaruh pembelajaran keuangan terhadap perilaku mahasiswa dalam mengelolah keuangan mereka antara lain penelitian Najmatul Laily (2013). Dia meneliti tentang Pengaruh Literasi Keuangan terhadap Prilaku Mahasiswa dalam Mengelolah Keuangan. Hasil penelitiannya menunjukkan bahwa ada pengaruh literasi keuangan terhadap prilaku mahasiswa dalam mengelolah Keuangan.(Najmatul Laily, 2013: Abstrak) Hasil penelitian ini berbeda dengan hasil penelitian yang dilakukan oleh Wulandari dan Lukman (2015). Mereka melakukan penelitian yang berjudul Pengaruh Love of Money, pendidikan keuangan di keluarga, Hasil Belajar Manajeman Keuangan dan Teman Sebaya Terhadap keuangan Pribadi Mahasiswa. Hasil penelitian menunjukkan bahwa Love of Mone, teman sebayadan pendidikan keuangan di keluarga berpengaruh positif terhadap keuangan pribadi mahasiswa sedangkan hasil belajar manajeman keuangan tidak berpengaruh terhadap keuangan pribadi mahasiswa.

Masih sedikitnya penelitian yang membahas tentang keuangan pribadi mahasiswa serta adanya perbedaan hasil penelitian yang dilakukan oleh peneliti terdahulu membuat peneliti ingin meneliti kembali penelitian tersebut. Pada penelitian ini peneliti ingin mengetahui bagaimana pemahaman mahasiswa STEBIS (Sekolah Tinggi Ekonomi dan Bisnis Syariah) terhadap pelajaran Akuntansi dengan pengalokasian dalam keuangan mereka. Pemahaman mahasiswa STEBIS dalam pelajaran Akuntansi ini diukur dari nilai mahasiswa STEBIS dalam mata kuliah Akuntansi. Adapun pengelolaan keuangan diukur dari uang saku yang diminta mahasiswa dari orang tuanya. Sehingga judul penelitian ini adalah Pengaruh Nilai Akuntasi Terhadap Pengelolaan Keuangan Mahasiswa STEBIS IGM.

\subsection{Rumusam Masalah}

Dari latar belakang yang sudah peneliti jelaskan di atas maka rumusan masalah dalam penelitian ini adalah :

"Bagaimana Pengaruh nilai Akuntasi terhadap pengelolaan keuangan Mahasiswa STEBIS IGM? “

\subsection{Hipotesis Penelitian}

Berdasarkan penelitian terdahulu dapat diketahui bahwa nilai akuntansi mahasiswa berpengaruh terhadap uang saku/uang jajan mahasiswa.

H1 : Nilai Akuntansi berpengaruh terhadap uang saku Mahasiswa

\subsection{Tujuan Penelitian}

Ada beberapa tujuan peneliti melakukan penelitian ini, adapun tujuan dari peneliti antara lain :

1. Untuk mengetahui sejauh mana mahasiswa STEBIS memahami pelajaran Akuntansi

2. Untuk mengetahui berapa pengeluran Mahasiswa STEBIS setiap bulannya

3. Untuk mengetahuiadakah pengaruh pembelajaran Akuntansi terhadap pengelolaan keuangan mahasiswa STEBIS

\subsection{Metodologi Penelitian}

Dalam penelitian ini data yang digunakan berupa angka dan analisis yang digunakan adalah analisis statistik, yang disebut dengan penelitian asosiatifkausal dengan pendekatan kuantitatif. Adapun proses pengujian dilakukan dengan analisis regresi linier sederhana. Dimana 
pada penelitian ini hanya terdapat satu variabel dependen (dipengaruhi) dan satu Variabel independen (mempengaruhi) . Variabel dependen dalam penelitian ini adalah uang saku, sedangkan variabel indpenden dalam penelitian ini adalah nilai akuntansi mahasiswa STEBIS.

Persamaan regresinya:

$$
\mathrm{Y} 1=\beta 0+\beta 1 \mathrm{X} 1+\mu
$$

Keterangan:

Y1 : Uang Saku

Bo Konstasnta

$\beta 1$ : Koefisien kemiringan parsial

X1 : Nilai Akuntansi

\section{PEMAHAMAN}

\subsection{Uang dan Uang Saku}

Uang dalam ilmu ekonomi tradisional didefinisikan sebagai setiap alat tukar yang dapat diterima secara umum. Dalam ilmu ekonomi modern, uang didefinisikan sebagai sesuatu yang tersedia dan secara umum diterima sebagai alat pembayaran bagi pembelian barang-barang dan jasa-jasa serta kekayaan berharga lainnya serta untuk pembayaran utang. (Abdul Mukhi, 2011 : 1)

Ada beberapa macam fungsi uang antara lain :

1. Alat tukar atau medium of exchange yang dapat mempermudah pertukaran.

2. Satuan hitung (unit of account) digunakan untuk menunjukan nilai berbagai macam barang/jasa yang diperjualbelikan, menunjukkan besarnya kekayaan, dan menghitung besar kecilnya pinjaman, juga dipakai untuk menentukan harga barang/jasa (alat penunjuk harga).

3. Alat penyimpan nilai (valuta) karena dapat digunakan untuk mengalihkan daya beli dari masa sekarang kemasa mendatang.

4. Standar pembayaran dimasa mendatang (standar of demand payment). (Abdul Mukhi, 2011 : 2)

Para ahli Ekonomi sudah memnahas tentang standar sesbuah benda dapat di jadikan sebagai uang. Benda tersebut harus memenuhi beberapa persyaratan, syarat tersebun antara lain :

a. Harus diterima secara umum (acceptability).

b. Memiliki nilai tinggi atau dijamin keberadaannya oleh pemerintah yang berkuasa.

c. Bahan yang dijadikan uang juga harus tahan lama (durability),

d. kualitasnya cenderung sama (uniformity),

e. jumlahnya dapat memenuhi kebutuhan masyarakat

f. tidak mudah dipalsukan (scarcity).

g. Harus mudah dibawa (portable) dan mudah dibagi tanpa

h. mengurangi nilai (divisibility)

i. memiliki nilai yang cenderung stabil dari waktu ke waktu(stability of value).

(Abdul Mukhi, 2011 : 2)

Adapun jenis uang sendiri, dibagi menjadi beberapa macam yaitu menurut bentuknya, jenisnya bahan pembuatnya dan nilainya. Pembagian uang menurut jenisnya antara lain :

1. uang kartal (sering pula disebut sebagai (common money) adalah alat bayar yang sahdan wajib digunakan oleh masyarakat dalam melakukan transaksi jual-beli sehari-hari.

2. uang giral, adalah uang yang dimiliki masyarakat dalam 
bentuk simpanan (deposito) yang dapat ditarik sesuai kebutuhan. (Abdul Mukhi, $2011: 3$ )

Selain menurut jenisnya pembagian uang juga dibagi berdasarkan bahan pembuatannya. Pembagian uang berdasarkan bahan pembuatannya antara lain :

1. Uang logam adalah uang yang terbuat dari logam; biasanya dari emas atau perak karena kedua logam itu memiliki nilai yang cenderung tinggi dan stabil, bentuknya mudah dikenali, sifatnya yang tidak mudah hancur, tahan lama, dan dapat dibagi menjadi satuan yang lebih kecil tanpa mengurangi nilai.

Uang logam memiliki tiga macam nilai:

a. Nilai intrinsik, yaitu nilai bahan untuk membuat mata uang, misalnya berapa nilai emas dan perak yang digunakan untukmata uang.

b. Nilai nominal, yaitu nilai yang tercantum pada mata uang ataucap harga yang tertera pada mata uang. Misalnya seratus rupiah(Rp. 100,00), atau lima ratus rupiah (Rp. 500,00).

c. Nilai tukar, nilai tukar adalah kemampuan uang untuk dapatditukarkan dengan suatu barang (daya beli uang). Misalnyauang Rp. 500,00 hanya dapat ditukarkan dengan sebuahpermen, sedangkan Rp. 10.000,00 dapat ditukarkan dengansemangkuk

bakso).(Abdul Mukhi, $2011: 3$ )

2. Uang kertas adalah uang yang terbuat dari kertas dengan gambar dan cap tertentu dan merupakan alatpembayaran yang sah. Menurut penjelasan UU No. 23tahun 1999 tentang Bank Indonesia, yang dimaksuddengan uang kertas adalah uang dalam bentuklembaran yang terbuat dari bahan kertas atau bahanlainnya (yang menyerupai kertas).(Abdul Mukhi, 2011 : 4)

Menurut para ahli Ekonomi pembagian uang juga berdasarkan nilainya. Pembagian uang juga berdasarkan nilainya :

1. Uang penuh (full bodied money) : apabila nilai yang tertera di atas uang tersebut sama nilainya denganbahan yang digunakan. Dengan kata lain, nilai nominalyang tercantum sama dengan nilai intrinsik yangterkandung dalam uang tersebut. Jika uang itu terbuatdari emas, maka nilai uang itu sama dengan nilai emasyang dikandungnya.

2. Uang tanda (token money) : adalah apabila nilai yangtertera diatas uang lebih tinggi dari nilai bahan yangdigunakan untuk membuat uang atau dengan kata lain nilai nominal lebih besar dari nilai intrinsik uangtersebut. Misalnya, untuk membuat uang Rp1.000,00 pemerintah mengeluarkan biaya Rp750,00.(Abdul Mukhi, 2011 : 4)

Terakhir yang akan peneliti bahas adalah adalah tentang pembagian uang berdasarkan bentuknya. Pembagian uang berdasarkan bentuknya terbagi menjadi 3 (tiga) yaitu :

1. Uang fiat (fiat money atau token money) : komoditas yang diterima sebagai uang namun nilai nominalnhya jauh lebih besasr dari nilai komoditas itu sendiri (intrinsiknya).

2. Uang komoditas (commodity money): uang yang nilainya sebesar nilai komoditas itu sendiri.

3. Uang hampir likuid (near money) : uang yang dalam penggunaannya perlu 
ditukar lebih dahulu, karena ini bukan subtitusi sempurna dari uang kertas atau logam. (Abdul Mukhi, 2011 : 5)

Adapun uang saku yang selama ini dipandang masyarakat luas hampir sama dengan uang jajan. Uang Jajan adalah uang diberikan untuk dibelanjakan sewaktuwaktu pada umumnya diberikan untuk anak-anak yang belum punya penghasilan dan jumlah tidak terlalu besar (Departemen Pendidikan Nasional, 2008:1512). Pada penelitian ini kemampuan mahasiswa dalam mengelolah keuangannya di ukur dengan banyaknya pengeluaran yang mereka butuhkan. Pengeluaran ini mengikuti uang saku yang diberikan para orang tua mereka setiap bulannya.

\subsection{Akuntansi dan Lingkungannnya.}

Sebelum kita membahas hubungan antara Akuntansi dengan kecakapan mahasiswa dalam mengelolah keuangan pribadi mereka, mari kita bahas terlebih dahulu pengertian Akuntansi dan lingkungannya, serta apa saja yang diharapkan mahasiswa setelah mempelajari akuntansi.

Akuntansi adalah sebuah kagiatan jasa. Fungsinya adalah penyedia informasi kuantitatif, terutama yang bersifat keuangan, tentang entitias ekonomi yang dimaksudkan agar berguna dalam pengambilan keputusan ekonomik. Dalam mengambil pilihan-pilihan beralasan di antara beberapa tindakan alternatif. (Slamet dan Agus, 2007:1)

Oleh karena pusat perhatiannya dalam organisasi, maka akuntansi dapat di klasifikasikan sesuai dengan organisasi. Klasifikasi demikian dapat digambatkan sebagi berikut : Gambar 1.1. Klasifikasi Akuntansi

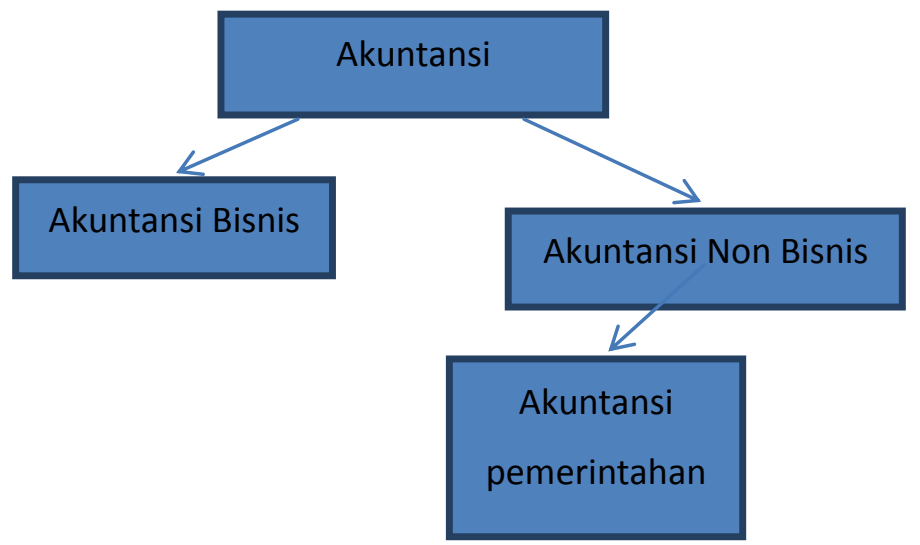

Dalam pelajaran akuntansi mahasiswa diajarkan berbagai macam kompetensi yang dibutuhkan mahasiswa untuk dapat memiliki keahlian dalam menyusun dan mengelolah laporan keuangan terutama keuangan perusahaan.

Mata kuliah akuntansi sendiri terbagi menjadi beberapa macam antara lain akuntansi pengantar satu, akuntansi pengantar dua, Akuntansi keuangan menengah, akuntansi syariah, akuntansi biaya.

Pada Akuntansi pengantar satu yang menjadi variabel dalam penelitian ini ada beberapa Bab yang dipelajari antara lain Akuntansi dalam Pandangan Umum, Laporan Keuangan, Analisis Transaksi, Buku Besar, Jurnal, Posting dan Neraca Saldo, Jurnal Penyesuaian, Jurnal Penutup, Neraca Lajur. Semua ini akan dipelajari mahasiswa dalam satu semester dalam jangka waktu 6 (enam) bulan, sebanyak 3 (tiga) SKS.

Adapun Harapan yang diharapkan setelah mempelajari pelajaran Akuntansi ini antara lain :

1. Mahasiswa mengetahui apa itu pelajaran akuntansi

2. Mahasiswa dapat membuat Jurnal, sehingga mahasiswa dapat menjurnal dan membalancekan antara pemasukan ke dalam debit dan pengeluaran yang dicatat dalam kredit 
3. Mahasiswa dapat membuat laporan laba rugi, sehingga dapat mengetahui apakah kita defisit atau surplus dalam keuangannya

4. Mahasiswa dapat membuat laporan neraca sehingga dapat membuat seimbang antara pemasukan dan pengeluaran

Setelah mahasiswa mempelajari pelajaran akuntansi, jika mahasiswa tersebut dapat mengaplikasikan ilmu yang telah dipelajari dalam kehidupan seharihari maka mahasiswa tersebut akan mempunyai catatan mengenai pemasukan dan pengeluaran pribadinya sehari-hari. Jika dia menghayati lebih dalam maka mahasiswa tersebut akan melakukan antisipasi yang membuat dia dapat menyisihkan sebagian uang yang dia miliki untuk disisihkan guna ditabung, agar jika dibutuhkan sewaktu-waktu maka mahasiswa ini tidak perlu meminjam dengan temamnya. Selain itu diharapkan para mahasiswa tidak boros dalam membelanjakan uang yang dia miliki.

\subsection{Penelitian Terdahulu}

Sebelum peneleliti sudah ada beberapa peneliti terdahulu yang telah melakukan penelitian yang sama. Irin Widayati (2012) melakukan penelitian yang berjudul Faktor-faktor yang Mempengaruhi Literasi Finansial Mahasiswa Fakultas Ekonomi dan Bisnis Universitas Brawijaya. Hasil penelitiannya menunjukkan bahwa status sosial, pendidikan keuangan dalam keluarga, pembelajaran perguruan tinggi berpengaruh terhadap literatur finansial sikap mahasiswa. (Irin Widayati, 2012 :1)

Najmatul Laily (2013) meneliti tentang Pengaruh Literasi Keuangan terhadap Prilaku Mahasiswa dalam Mengelolah Keuangan. Hasil penelitiannya menunjukkan bahwa ada pengaruh literasi keuangan terhadap prilaku mahasiswa dalam mengelolah Keuangan. (Najmatul Laily, 2013: Abstrak)

Fatimatus Zahrah (2014) menguji tingkat pengetahuan keuangan, sikap keuangan dan prilaku pribadi mahasiswa Jurusan Manajemen Fakultas ekonomi dan Bisnis Semester 3 dan 7. Hasilnya menunjukkan bahwa terdapat perbedaan antara tingkat pengetahuan keuangan, sikap keuangan dan prilaku pribadi mahasiswa.( Najmatul Laily, 2013: Abstrak)

Nyoman Trisna Herawati (2015) melakukan penelitian yang berjudul Kontribusi Pembelajaran di Perguruan Tinggi dan Literasi Keuangan Terhadap Perilaku Keuangan. Hasil penelitianny menunjukkan bahwa terdapat pengaruh pembelajaran di perguruan tinggi dan literasi keuangan terhadap perilaku keuangan mahasiswa. Nyoman Trisna Herawati, $2015: 1$ )

Wulandari dan Lukman (2015) melakukan penelitian yang berjudul Pengaruh Love of Money, pendidikan keuangan di keluarga, Hasil Belajar Manajeman Keuangan dan Teman Sebaya Terhadap keuangan Pribadi Mahasiswa. Hasil penelitian menunjukkan bahwa Love of Money, teman sebaya dan pendidikan keuangan di keluarga berpengaruh positif terhadap keuangan pribadi mahasiswa sedangkan hasil belajar manajeman keuangan tidak berpengaruh terhadap keuangan pribadi mahasiswa (Wulandari dan Lukman, 2015 : 1)

M. Habib Ristiono (2016) melakukan penelitian yang berjudul Peran Mata kuliah Manajemen Keuangan dalam Pengelolaan Keuangan Pribadi Mahasiswa (Studi Kasus Mahasiswa Pendidikan IPS UIN Maulana Malik Ibahim). Hasil 
penelitian ini menunjukkan bahwa ada pengaruh mata kuliah Manajemen Keuangan dalam pengelolaan keuangan pribadi mahasiswa. (M. Habib Ristiono, 2016 : Abstrak)

\subsection{Gambaran Umum STEBIS IGM}

Sekolah Tinggi Ekonomi dan Bisnis Syariah Indo Global Mandiri yang berdiri di bawah naungan Yayasan Indo Global Mandiri, kemudian dikenal dengan singkatan STEBIS IGM. Faktor pembangunan STEBIS IGM antara lain, pertama ide pembangunan sekolah tinggi ini muncul dari para pendiri yayasan dan tumbuhnya lembaga-lembaga keuangan syariah seperti bank, asuransi, pegadaian, pembiayaan, dan lain-lain serta menguatnya kembali ekonomi Islam di dunia. Kedua, pertimbangan bahwa perguruan tinggi swasta berbasis syariah belum ada di Sumatera Selatan. Ketiga pertumbuhan madrasah, pesantren dan perguruan agama sederajat dengan SLTA tumbuh berkembang, yang pada gilirannya memerlukan adanya lembaga pendidikan lebih tinggi. Disamping itu perkembangan zaman dan tuntutan masa memang memerlukan tenaga ahli yang profesionalterampil dalam bidang perekonomian syariah.

STEBIS IGM memiliki dua program studi yaitu: Program Studi Ekonomi Syariah untuk jenjang S1 dan Perbankan Syariah untuk jenjang D3 yang terdaftar di Kopertais Wilayah VII Sumbagsel dengan izin penyelenggaraan yang diberikan oleh Dirjen Pendidikan Islam SK Nomor 2516 tahun 2014 tanggal 5 Mei 2014 tentang Persetujuan Pendirian Perguruan Tinggi Agama Islam Swasta. STEBIS IGM beralamat di Gedung Kampus A Lantai 5, Jl. Jenderal Sudirman No. 629 KM.4 Palembang.
Hingga saat ini jumlah mahasiswa STEBIS IGM terus mengalami peningkatan. Pada awal dibentuk jumlah mahasiswa STEBIS IGM adalah 42 Orang yaitu mahasiswa Ekonomi Syariah sebanyak 30 orang dan mahasiswa Perbankas Syariah sebanyak 12 orang. Pada tahun berikutnya jumlah mahasiswa ini meningkat kembali, saat ini jumlah mahasiswa STEBIS IGM mencapai 108 mahasiswa. Adapun jumlah dosen yang mengajar di STEBIS IGM kurang lebih 12 orang dosen tetap masing-masing 6 dosen tetap prodi ekonomi syariah dan 6 lagi merupakan dosen tetap prodi perbankan syariah.

\section{HASIL DAN PEMBAHASAN}

\subsection{Populasi dan Sampel}

Populasi dalam penelitian ini adalah mahasisa STEBIS IGM baik perbankan syariah maupun ekonomi Syariah angkatan 2015 dan 2016. Keseluruhan mahasiswa tersebut berjumlah 62 mahasiswa. Namun ada beberapa mahasiswa yang tidak bisa dijadikan sampel di dalam penelitian ini karena mengambil mereka menjadi sampel dalam penelitian ini akan membuat data penelian ini menjadi bias.

\section{Tabel 3.1}

\section{Proses Pengambilan Sampel}

\begin{tabular}{cc}
\hline Jumlah Mahasiswa & 62 \\
Angkatan 2015-2016 & \\
Data outlier & 14 \\
Jumlah Sampel & 48 \\
\hline Sumber : data sekunder yang diolah
\end{tabular}

\subsection{Analisis Regresi Linier Sederhana}

Penelitian ini menggunakan analisis regresi linier sederhana. Adapun variabel independen dalam penelitian ini adalah nilai Akuntansi 
sedangkan variabel dependennya adalah uang saku.

Persamaan regresinya:

$$
\mathrm{Y} 1=\beta 0+\beta 1 \mathrm{X} 1+\mu
$$

\section{Keterangan:}

Y1 : Uang Saku

Bo : Konstasnta

$\beta 1$ : Koefisien kemiringan parsial

X1 : Nilai Akuntansi

\subsection{Hasil Uji Normalitas}

Sebelum diuji sebuah data harus di pastikan terlebih dahulu lulus ujinormalitas. Pada penelitian ini uji normalitas yang digunakan adalah One kolmogorof smirnov test. Sebuah data dikatakan normal jika data tersebut memiliki nilai signifikansi > 0,05 . (Ghozali, 2011 : 163) . Pada penelitian ini data yang sudah diuji memiliki nilai signifikansi yang semuanya di atas 0,05.

Tabel 3.2

\begin{tabular}{ll}
\multicolumn{2}{l}{ One kolmogorof smirnov test } \\
\hline Variabel & Nilai test \\
Uang Saku & 0,058 \\
Nilai & 0,748
\end{tabular}

Akuntansi

Sumber : data sekunder yang diolah

\subsection{Hasil Signifikansi Uji t}

Variabel independen dikatakan memiliki pengaruh terhadap variabel independen apabila nilai signifikansi uji-t nya memiliki nilai yang lebih kecil dari pada 0,05. Hasil uji signifikasni nilai Akuntansi terhadap uang saku mahasiswa dapat dilihat dapat dilihat dalam tabel 3.3di bawah ini
Tabel 3.3

Hasil uji t

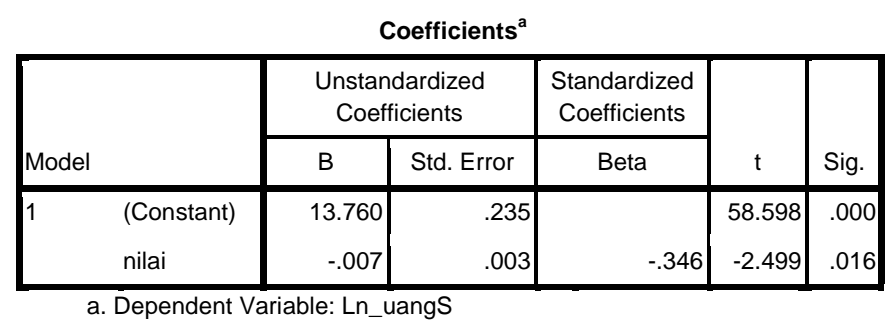

Sumber : hasil output SPSS

Dari hasil output SPSS di atas dapat diambil kesimpulan bahwa nilai akuntansi memiliki pengaruh terhadap uang saku mahasiswa. Hal ini bisa dilihat dari nilai signifikansi 0,016. 0,016 < 0,05, jadi dapat ditarik kesimpulan bahwa nilai akuntansi berpengaruh negatif dan signifikan terhadap uang saku mahasiswa. Dari sini dapat disimmpulkan bahwa H0 ditolak dan hipotesis diterima.

H1 : Nilai Akuntansi berpengaruh terhadap uang saku mahasiswa

Hal ini berarti semakin tinggi nilai Akuntansi mahasiswa, pengeluaran mereka semakin banyak. Hal ini menunjukkan bahwa tidak semua mahasiswa yang pintar dalam Akuntansi mampu mengelolah keuangan mereka. Mereka mungkin mampu dalam praktik namun belum mampu sepenuhnya mengaplikasikan ilmu yang mereka miliki dalam Pengelolaan keuangan mereka. Oleh sebab itu diperlukan perhatian dan pengertian terutama pengertian dalam psikologis mereka agar dapat mengaplikasikan ilmu yang telah mereka miliki untuk dapat di amalkan dalam kehidupan sehari-hari. 


\section{KESIMPULAN DAN SARAN}

\section{Kesimpulan}

Hasil penelitian ini menunjukkan bahwa nilai Akuntansi berpengaruh terhadap uang saku/uang jajan mahasiswa. Oleh sebab itu hipotesis dalam penelitian ini diterima. Nilai signifikansi 0,016 , nilai ini $<0,05$. jadi dapat ditarik kesimpulan bahwa nilai akuntansi berpengaruh negatif dan signifikan terhadap uang saku mahasiswa. Hal ini berarti semakin tinggi nilai Akuntansi mahasiswa, pengeluaran mereka semakin banyak. Hal ini menunjukkan bahwa tidak semua mahasiswa yang pintar dalam Akuntansi mampu mengelolah keuangan mereka.

\section{Saran}

Para mahasiswa STEBIS mungkin mampu dalam praktik namun belum mampu sepenuhnya mengaplikasikan ilmu yang mereka miliki dalam Pengelolaan keuangan mereka. Oleh sebab itu diperlukan perhatian dan pengertian para orang tua terutama pengertian dalam psikologis mereka agar dapat mengaplikasikan ilmu yang telah mereka miliki untuk dapat di amalkan dalam kehidupan sehari-hari.

\section{DAFTAR PUSTAKA}

Fatimatus Zahra. 2014. Menguji Tingkat Pengetahuan Keuangan, Sikap Keuangan dan Prilaku Pribadi Mahasiswa Jurusan Manajemen Fakultas ekonomi dan Bisnis Semester 3 dan 7.Skripsi. Fakultas Ekonomi dan Bisnis Universitas Diponogoro.

Ghazali, Imam. Aplikasi Multivariate dengan Program SPSS. 2011. Yogyakarta : Badan Penerbit Universitas Diponogoro.
Irin Widiyati. 2012. Faktor-faktor yang Mempengaruhi Literasi Finansial Mahasiswa Fakultas Ekonomi dan Bisnis Universitas Brawijaya. Jurnal Akuntansi dan Pendidikan Vol.1 No. 1

Najmatul Laily. 2013. Pengaruh Literasi Keuangan terhadap Prilaku Mahasiswa dalam Mengelolah Keuangan. Jurnal Pendidikan Akuntansi. Vol. No.4

Nyoman Trisna Herawati. 2015. Kontribusi Pembelajaran di Perguruan Tinggi dan Literasi Keuangan Terhadap Perilaku Keuangan. Jurnal Pendidikan dan Pengajaran, Jilid 48 Vol. 1 No.3

Mohammad Abdul Mukhyl. 2011. Uang dan Lembaga Keuangan. mukhyi.staff.gunadarma.ac.id/Downl oads, diakses tanggal 26 Januari 2016)

M. Habib Ristiono. 2016. Peran Mata kuliah Manajemen Keuangan dalam Pengelolaan Keuangan Pribadi Mahasiswa (Studi Kasus Mahasiswa Pendidikan IPS UIN Maulana Malik Ibahim). Skripsi.Universitas Islam Negeri. Maulana Malik Ibahim

Slamet Sugiri dan Bogat Agus Riyono.2007. Akuntansi Pengantar 1 Edisi ke-enam. Yogyakarta : UPP STIM YKPN

Wulandari, Lukman Hakim. 2015. Pengaruh Love of Money, pendidikan keuangan di keluarga, Hasil Belajar Manajeman Keuangan dan Teman Sebaya Terhadap Keuangan Pribadi Mahasiswa. 